\title{
Poemas chineses
}

\author{
Alberto Marsicano \\ Chiu Yi Chih \\ Chiu Si-Yuan
}

Considerado o maior dos poetas chineses, Li Bai (Li Pó) (701-762) viveu na dinastia Tang, a era de ouro da poesia chinesa. São atribuídos a ele mais de mil poemas, que vêm influenciando a cultura chinesa há séculos.

\section{Sobre a tradução:}

O professor Chiu Si-Yuan traduzia diretamente do mandarim enquanto Alberto Marsicano e Chiu Yi Chih aprimoravam no português. Apresentamos aqui três versões de dois poemas de Li Bai. Outras versões desses dois poemas em traduções nos estilos renascentista (soneto), árcade e cubo-futurista estão sendo elaboradas e possivelmente serão publicadas no nosso livro de antologia da poesia clássica chinesa. Mas por que elaborar várias traduções para um mesmo poema? Após conviver anos com o grande mestre tradutor Haroldo de Campos ${ }^{1}$, e traduzir Blake, Wordsworth, Shelley e Keats com o virtuose John Milton, professor titular da USP, Alberto Marsicano chegou à conclusão de que não existe 'a' forma verdadeira de traduzir um poema, mas várias, igualmente corretas. Qual câmera que com várias lentes focaliza o mesmo objeto, os poemas de Li Bai aqui apresentados foram traduzidos em três versões diferentes: literal, rimada e ideogrâmica. E embora essas traduções ao português tenham sido feitas conjuntamente por Alberto Marsicano e Chiu Yi Chih, a partir da tradução literal e precisa do

1 Escreveu o prefácio e a introdução de duas traduções suas: "Haikai - Antologia da poesia clássica japonesa" e "Sijô Poesiacanto Coreana Clássica". 
mandarim por Chiu Si-Yuan, a ideia de fazer várias versões do mesmo poema e a iniciativa de fazer uma tradução rimada (não há rimas na poesia chinesa) são de Alberto Marsicano.

Durante o trabalho, deparamo-nos com a delicada tarefa de transpor a estrutura sintética dos poemas, o que nos levou à extrema concisão no processo de tradução. A visualidade ideogrâmica e a riqueza imagética da poesia chinesa foram aspectos fundamentais que exigiram bastante cuidado de nossa parte, incluindo o próprio universo cifrado e simbólico dos poemas. E que 'universo cifrado' seria esse? A menção aos "lótus brancos" em um dos poemas de Li Bai é um bom exemplo: o leitor ocidental não tem acesso à verdadeira poesia chinesa com sua miríade de significados. As traduções apenas apresentam o sentido literal do poema, não decodificando seu conteúdo criptográfico. Li Bai foi perseguido pelo imperador por ser amante da imperatriz e teve de fugir para o exílio para salvar a própria vida. Quando o leitor lê na tradução ocidental "os lótus brancos fluem na corrente para bem longe do mundo dos homens" pensa ser este um belo verso naturalista, mas não penetra no sentido cifrado onde os 'lótus brancos' simbolizam Li Bai (branco, em chinês), escapulindo na corrente, da corte e das intrigas palacianas (o 'mundo dos homens'). Em outro poema de Li Bai, “a Dama espera na alta torre a volta do pássaro da primavera". O pássaro é Li Bai e a dama, a imperatriz.

O recurso a palavras justapostas, como "florespessegueiro" no poema "Diálogo no monte" remete a James Joyce ('silvamoonlake') e Ezra Pound, inspirados por sua vez em Fenollosa. Desde Joyce e Pound, este é um recurso poético corrente: utilizar recursos e justaposição de conceitos das línguas analógicas como o chinês, nas digitais como o português. O próprio Marsicano já tinha usado esse recurso em sua tradução "Haikai - antologia da poesia clássica japonesa" com experimentações como 'vermelhibélulas', entre outras.

\section{Bebendo sozinho ao luar}

Entre flores o cântaro de vinho.

Bebo só sem algum amigo

Ergo a taça e brindo a lua:

Com ela e a minha sombra, somos três.

A lua não bebe, e minha sombra segue o que faço.

A sombra e lua, frugais companheiras

Celebram comigo na primavera.

Quando canto, a lua oscila. 
Quando danço, minha sombra rodopia.

Embriagados, divertimo-nos.

Depois, cada um volta para casa.

Junto a esses insensíveis companheiros:

Nossos encontros são pela Via Láctea.

\section{Bebendo só ao luar}

O cântaro de vinho entre flores

Bebo só sem algum amigo

Ergo a taça a lua brinda comigo

Com minha sombra somos três

A sombra e a lua frugal companheira

Celebram comigo na primavera

Quando canto a lua reverbera

Quando danço minha sombra gira

Ébrios nos divertimos

Após cada qual volta ao lar

Com os insensíveis companheiros

$\mathrm{Na}$ Via Láctea vamos nos encontrar.

\section{Bebendo só ao luar}

FLORES

CÂNTARO DE VINHO

SOLITÁRIO

BEBER

SEM AMIGO

COM TAÇA

CONVIDAR

LUA

COM SOMBRA

LUA

TORNAR-SE

TRÊS 
LUA

ENTÃO

NÃO BEBER

SOMENTE

SOMBRA

AO LADO

LUA

SOMBRA

EM COMPANHIA

SER

FELIZES

NA PRIMAVERA

CANTAR

LUA

AO REDOR

DANÇAR

SOMBRA

EM GIROS

ACORDAR

TODOS JUNTOS

FELICIDADE

APÓS BÊBADO

TODOS

AFASTAR-SE

SEMPREJUNTOS

INSENSÍVEIS

COMPANHEIROS

ESPERANÇA

ENCONTROS

PELA VIA LÁCTEA 


\section{月下獨酌}

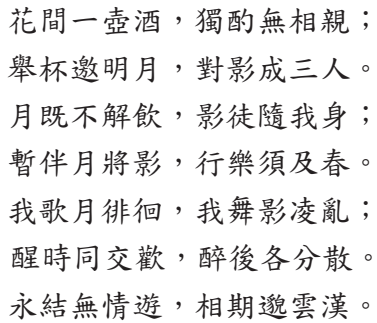

\section{Diálogo no monte}

Por que vivo no verde monte?

Sorrio sem resposta

Flores do pessegueiro fluem na corrente do rio

Há outro céu, outra terra, além do mundo dos homens.

\section{Diálogo no monte}

Por que vivo no verde monte?

Sorrio incerto simplesmente

Flores fluem pela corrente

Há outro mundo além do borizonte.

Diálogo no monte

POR QUE

FICAR

NA MONTANHA

SERENO

FLORESPESSEGUEIRO

CORRENTE

FLUIR

EXISTIR

ESPAÇO

OUTRO

DAQUI 
山中問答

問余何意棲碧山 笑而不答心自閑 桃花流水查然去

別有天地非人間 